\title{
PSYCHOLOGICAL MEANS OF RECREATION SPORTSMEN'S PSYCHIC WORKABILITY
}

\author{
Gant H.Y., Orlenko O.M.
}

Kharkov State Academy of Physical Culture

Abstract. Purpose: to study recreation of sportsmen's psychic workability under influence of psychological methods. Material: Students-sportsmen, practicing boxing and kickboxing ( $\mathrm{n}=45$, age17-23 years) participated in he research. Express assessment methodic for "Self-feeling, activity and mood", "Correcting tests" was used. Results: sportsmen's subjective assessment of own state depends on the stage of competition functioning. This assessment is rather favorable in pre-competition and competition periods. In pre-competition period unconscious weakening of psychic workability happens. Psychic workability weakening in competition period is of functional character and can be reduced in post-competition period. Conclusions: application of art-therapeutic methodic results in sportsmen's more recreated, relaxed and hardy. Singing and drawing can be used as the method of stabilization of sportsmen's activity, mood and self-feeling.

Key words: art therapy, psychology, sportsmen, boxing, psychic workability.

\section{Introduction}

Recent time the problem of human psychic activity regulation has been attracting attention of many researchers. Importance of this problem is determined by its significance for solution of many tasks of fundamental and applied psychology. Indeed, human ability to control own functioning for solution of the chosen tasks is of key importance for its adaptation in different life activity and sports spheres [24, 29, 31]. Solution of this problem is of special importance in physical education of youth [6].

In modern society high requirements are set to sportsman on development of his regulatory processes, which would permit for him to be a genuine subject of own behavior and to independently determine own prospects $[4,5,7]$. Formation of sportsmen's abilities of psychic self-regulation is important for maximal realization of their potentials in extreme conditions of sports functioning. Among factors of self regulation mechanisms' formation central place belongs to psychic workability, which determines direction and level of subject's functioning [17, $22]$. Such functioning is a component of martial arts sportsmen's training $[1,26]$. In this case it is necessary to objectively assess sportsmen's potentials for quick recreation of his physical and psychic workability. Recreation of psychic workability takes more time than recreation of physical workability. That is why one of promising directions of the research is study of psychic functioning arbitrary regulation in stress conditions. It was found that absence of ability for arbitrary regulation of psychic functioning under stress factors' influence is one of reasons of sportsmen's affective and behavioral dysfunctions [20, 22, 28].

Analysis shows that ability of psychic workability recreation is the basic component of sportsmen's successful psychological training. It ensures holistic training and competition processes in martial arts [15, 20, 26]. Alongside with it, at present there are no systemized ideas about laws of psychic workability's effective recreation mechanisms' formation in martial arts in training and competition periods. The question of training and competition extreme conditions' influence on sportsmen's functional state has been remaining practically not studied. It emphasizes on the urgency of this research. Need in scientific working out of tools for complex assessment of sportsmen's psychic workability is evident. Its important component is development of programs for recreation of sportsmen's psychic workability at different stages of sports functioning. For solution of this, rather difficult, circle of problems special complex psycho-diagnostic study, oriented on analysis of the whole spectrum of sportsmen's psychic workability mechanisms, is required. It is of great significance for working out the program of sportsmen's psychic workability recreation and for predicting their professional functioning successfulness.

The purpose of the work is to study recreation of sportsmen's psychic workability under influence of psychological means.

(C) Gant H.Y., Orlenko O.M., 2016

doi:10.15561/20755279.2016.0501 


\section{Material and methods}

Participants: students-sportsmen, practicing boxing and kickboxing ( $\mathrm{n}=45$, age 17-23 years) participated in he research. Among them there were 19 elite sportsmen. Randomly the sportsmen were divided into 2 groups: control and experimental.

Organization of the research: the research was carried out in several stages. For studying psychic workability (concentration of attention, stability of attention, re-switching of attention) in control and experimental groups we used methodic (Correction tests). Testing was conducted: before training, just after training and 40 minutes after training. We used special forms with lines of randomly located letters. Sportsmen looked through the form line by line and crossed out the pointed in instruction letters. With it (after every 60 seconds) by command they marked the looked through quantity of letters by vertical line [23]. The methodic of express assessment of self-feeling, activity and mood (SAM) was used for assessment of sportsmen's actual state. The sportsmen were offered to describe their state in the given moment with the help of table, consisting of 30 pairs of polar qualities. In every pair it was necessary to choose the quality, which describes sportsman's state the most accurately and mark the number, which corresponds to degree of this characteristic's expressiveness [17].

The next stage of the research was study of art-therapeutic techniques for recreation of sportsmen's psychic workability. Experimental group sportsmen were offered to sing in chorus: just after training; during changing cloth and hygienic procedures. After singing sportsmen assessed their mood, state and activity by SAM scale [17] and fulfilled methodic "Correcting tests" [23].

Besides, as art-therapeutic methodic for sportsmen's psychic workability recreation we used technique "Intuitive drawing". This technique implies topic-free drawing. Experimental group sportsmen were offered to draw picture just after training. Drawing shall be fulfilled alternatively by right and left hands wit open and closed eyes. Topics and materials were chosen by sportsmen independently. Time for picture drawing was unlimited. After drawing sportsmen assessed their mood, state and activity by SAM scale [17] and passed "Correcting tests" [23].

Statistical analysis: for every studied indicator we calculated mean values and mean square deviation. Confidence of differences between mean values was determined by Student's t-criterion at $1 \%$ and $5 \%$ of significance levels [11].

\section{Results of the research}

Before training process we found in sportsmen the following: mean values of "self-feeling" indicators (good self-feeling) (5.93 \pm 1.07$)$; feeling own strength (5.93 \pm 0.73$)$; feeling workability $(5.71 \pm 1.44)$; feeling power (5.50 \pm 1.29$)$; cheerfulness (5.14 \pm 1.10$)$; feeling hardy (5.29 \pm 1.68$)$; feeling healthy $(6.07 \pm 1.00)$. These indicators

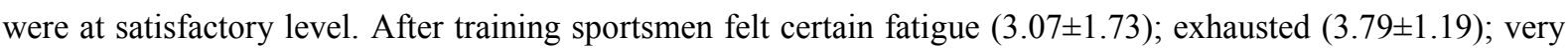

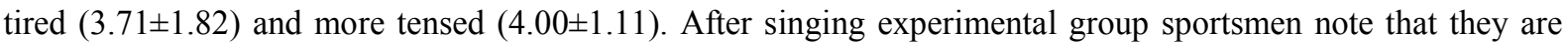
more fresh $(5.33 \pm 1.44)$ and hardier $(5.58 \pm 1.16)$. By these maximal indicators differences were not confident $(\mathrm{p}<0.05)$. Besides, they not that they are rested $(5.33 \pm 1.44)$ and more relaxed $(5.58 \pm 1.16)$ (differences are confident at $\mathrm{p}<0.05)$. After drawing pictures control group sportsmen noted wish to work $(4.71 \pm 1.89)$ and increased attention $(5.71 \pm 0.87)$. In pre-training period mean values of this criterion stabilized up to initial level (differences are not confident, $\mathrm{p}>0.05$ ).

In pre-training period the following mean values of indicators are at rather satisfactory level: "activity" (feeling of activity-passivity, 5.43 \pm 1.16 ); mobility (5.57 \pm 1.28 ); quickness (5.14 \pm 1.17 ); wish to function (5.50 \pm 1.09$)$; feeling of indifference-enthusiasm (5.46 \pm 0.93$)$; indifference - excitement (4.79 \pm 1.19$)$; drowsiness -

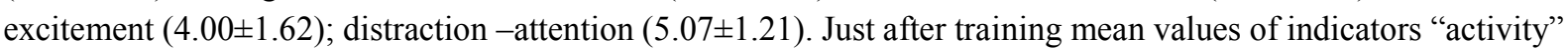
differ from mean values of "activity" before training: sportsmen feel themselves less quick (4.86 \pm 1.03$)$; more distracted (4.93 \pm 1.21$)$; having wish to rest $(3.57 \pm 1.91)$. With it this differences are not confident. Confident differences were in indicator: feel more excited $(5.29 \pm 1.68)$, than before training.

40-60 minutes after singing technique sportsmen note growth of wish to work (4.58 \pm 1.78$)$. Mean values by this criterion are stabilized up to initial level in pre-training period (differences are not confident, $p>0.05$ ). Besides, there is confident reduction by indicators "drowsiness-excitement" (3.33 \pm 1.83$)$. 40-60 minutes after drawing pictures' technique experimental group sportsmen not increased wish to work (4.71 \pm 1.89$)$. Mean indicators by this criterion stabilize up to initial level in pre-training period (difference are not confident, $p>0,05$ ). 
In pre-training period rather at satisfactory level are indicators "mood": feeling joyful-sad $(5.50 \pm 1.70)$; happy-unhappy (5.89 \pm 1.18$)$; cheerful-cheerless (5.57 \pm 1.34$)$; satisfied (5.86 \pm 1.03$)$; full of hopes (5.57 \pm 1.70$)$. By results of after training testing we registered rising of mood (6.14 \pm 1.10$)$, enthusiasm (5.29 \pm 1.07$)$, feeling of satisfaction $(6.29 \pm 1.07)$ but weakening of optimism $(5.57 \pm 1.28)$ and state of relaxation $(4.79 \pm 1.42)$. The differences are not confident ( $\mathrm{p}>0,05)$.

After "Song" technique, before training sportsmen's indicators are higher than initial training: "happy" (6.42 \pm 0.51$)$; "cheerful" (6.33 \pm 0.89$)$; “joyful" (6.08 \pm 0.90$)$. Indicators "calm" (5.42 \pm 1.24$)$, "optimistic" $(6.08 \pm 0.90)$ stabilized up to initial level. With it difference were confident at $(p>0.05)$. After drawing, before training indicators by criteria "happy", "cheerful", "joyful" also increased higher than initial level and indicators be criteria "calm" and "optimistic" stabilized up to initial level with not confident differences at ( $p>0.05)$.

After application art-therapeutic techniques indicators of concentration of attention in control (58.3 \pm 5.9$)$ and experimental $(69.8 \pm 13.8)$ groups had statistically not confident differences at $p>0.05$. The same was with indicator of attention stability. Indicators of attention re-switching in control group were insignificantly lower than in experimental group $(p>0,05)$.

\section{Discussion}

We received new data, permitting to timely correct content of sportsmen's psychological recreation program of in conditions of training process with the help of art-therapy. We found peculiar features of sportsmen's psychological workability, self-feeling, activity and mood on different stages of training process.

In opinion of S. Skeify indicators for art-therapy in sportsmen are: difficulties of emotional development, actual stress, depression, weakening of emotional tonus, emotional deprivation, lability, impulsivity of emotional reactions, feeling of emotional rejection, feeling of isolation, conflicts in interpersonal relations, non satisfaction in family, jealousy, increased anxiety, fears, phobias, low self-assessment, and low degree of self-perception [19]. In our study we used art-therapeutic techniques for recreation sportsmen's psychic workability.

Correcting potentials of art-therapy are connected with providing a client with practically unlimited opportunities for self-expression and self-realization in art $[2,8,12,16]$. We found that after free singing and intuitive drawing pictures sportsmen's actual state improves. Free singing and intuitive drawing positively influenced on recreation of sportsmen's psychic workability. So we can say that art-therapeutic techniques can be used for recreation of sportsmen's psychic workability. It will permit to stabilize sportsmen's activity, mood and self-feeling.

General principles of art-therapy correction potentials are presented in works by A.I. Kopytin [12, 13]. When drawing pictures, client shall have opportunity to tell about the picture; to describe definite forms, objects, characters. Sportsman shall have opportunity to focus attention on colors. In other research it is noted that focusing on colors helps to understand actual emotions and feelings [10]. In drawing pictures we recommended sportsmen to pay special attention to the absent parts of picture and empty space on sheet as well as to tell about own feeling in the process of drawing, before it and after it. In research [12] author notes that client shall have opportunity to work in convenient for him temp. The client shall comprehend future picture and reflect his state in it. In our research we gave sportsmen opportunity to feel that they control drawing process and its results by themselves.

In other work it is noted that free singing positively influences on human targeted functioning. Positive emotional feelings, when singing pleasant melodies, strengthen attention, activate emotional central nervous system and stimulate intellectual activity [21]. Results of our research prove that free singing confidently improves sportsmen's mood.

A.I. Kopytin thinks that free singing and drawing are good stress-releasing and emotional stability keeping means. In free thinking and drawing those emotions are felt and splashed out, which can not be released even with tears [12]. We found that after singing or drawing sportsmen felt themselves fresher, headier, relaxed.

With it G. Ruthann [18] notes that singing favorite melodies positively influences on human targeted functioning. Such approach facilitates such organism's rhythmic tuning, which results in more effective processes in organism. Positive emotional feelings, when singing pleasant melodies, strengthen attention, activate central nervous system and stimulate intellectual activity [3, 13, 18, and 27].

The main criterion for psychological methods' selection for sportsmen' psychic workability recreation shall be desire of sportsmen themselves to sing or to draw [8]. In our study we determined effectiveness of the 
offered exercises and techniques for recreation of psychic workability. It permits to recommend their application in trainings and out of trainings.

Coaches are recommended to control main indicators of sportsmen's psychic workability during all year. It will permit to select effective means and methods of influence on the studied characteristics, the level of which determines sportsmen's readiness for effective interaction and high sport efficiency. Analysis of correlation of some indicators of sportsmen's functional state showed that in pre-competition period there is unconscious weakening of psychic workability. In conditions of competition functioning such weakening is of functional character and can be reduced in post-competition period.

\section{Conclusions}

Sportsmen's subjective assessment of their state depends on the stage of competition functioning as well as on pre- and post- competition periods.

After singing or drawing, sportsmen notice increase of freshness and relaxation of their state (5-7 minutes after training). Such indicators are absent in case of usual after-training rest (during 30-40 minutes). After singing, wish to work appears in sportsmen. Besides, indicators by criteria "happy", "cheerful", "joyful" increase up to level above initial (before training). In pre-training period we observed stabilization of indicators up to initial level by criteria "calmness", "optimistic". Singing and drawing can be used as method of sportsmen's psychic workability recreation. It stabilizes their activity, mood and self-feeling.

\section{Conflict of interests}

The authors declare that there is no conflict of interests.

\section{References}

1. Belykh SI. Effektivnye metody podgotovki kikbokserov [Effective methods of kick-boxers' training], Slobozhans'kij naukovo-sportivnij visnik, 2009; 3: 332-335 (in Russian)

2. Bekker-Glosh V. Art-terapiia v aleksianerovskoj psikhiatricheskoj bol'nice [Art-therapy in alexianery psychiatric hospital], Sankt Petersburg; 2001. (in Russian)

3. Burno ME. Klinicheskaia psikhoterapiia [Clinical psycho-therapy], Moscow; 2000. (in Russian)

4. Belykh SI, Eremenko VV, Marabian AV. Usovershenstvovanie trenirovochnogo processa $v$ khode podgotovki kikbokserov [Perfection of training process in kick-boxers' training], Slobozhans'kij naukovosportivnij visnik, 2007; 11: 9-122. (in Russian)

5. Bleer AN. Psikhologicheskie faktory obespecheniia ustojchivosti psikhomotornykh dejstvij v edinoborstvakh [Psychological factors of psycho-motor actions' stability in martial arts]. Sportivnyj psikholog, 2008; 2: 2630. (in Russian)

6. Gant OIe. Vpliv profesijnogo stresu na osobistist' sportsmeniv [Influence of professional stress on sportsmen's personalities]. I Mizhnarodna konferenciia Ievrazijs'kogo naukovogo rozvitku, Viden', Avstriia, kviten' 2014 [1st International conference of Euro-Asian scientific development, Vienna, Austria, April, 2014], 2014. P. 250-255. (in Ukrainian)

7. Gant OIe. Vpliv situacii ekstremal'noi sportivnoi diial'nosti na samoocinku sportsmeniv [Influence of extreme sport functioning on sportsmen's self-assessment]. XVIII regional'naia nauchno-prakticheskaia konferenciia uchitelej "Obrazovanie kak faktor formirovaniia innovacionnogo chelovecheskogo potenciala”, Khar'kov, 14 aprelia 2012 g. [18th regional scientific-practical conference of teachers "Education as factor of formation of human innovative potential", Kharkov, April 14, 2012], 2012. P. 64-69. (in Ukrainian)

8. Gant OIe. Metodi art-terapii u roboti sportivnogo psikhologa [Art-therapy methods in work of sports psychologist], Kharkiv: KHFAFK; 2014. (in Ukrainian)

9. Gant OIe, Malik IaK. Sportivna diial'nist' iak osoblivij vid profesional'nogo funkcionuvannia liudini [Sport functioning as special kind of human professional functioning]. Problemi ekstremal'noi ta krizovoi psikhologii, 2014;17: 62-73. (in Ukrainian)

10. Inkmann L, Kunst Haus Kannen. Art-terapiia [Art-therapy], Sankt Petersburg; 2001. (in Russian)

11. Kobzar' AI. Prikladnaia matematicheskaia statistika [Applied mathematical statistic], Moscow; 2006. (in Russian)

12. Kopytin AI. Sistemnaia art-terapiia [Systemic art-therapy], Sankt Petersburg; 2001. (in Russian) 
13. Kopytin AI. Teoriia i praktika art-terapii [Theory and practice of art-therapy], Sankt Petersburg; 2002. (in Russian)

14. Makarov VV. Lekcii po psikhoterapii. [Lectures on psycho-therapy], Moscow; 2000.(in Russian)

15. MakNiff Sh. Tvorchestvo za ramkami privychnogo: rasshirenie vozmozhnostej psikhologicheskikh issledovanij s pomoshch'iu iskusstva [Creative work out of usual: expansion of potentials with the help of art], Isceliaiushchee iskusstvo, 2002;5(3):8-25. (in Russian)

16. Peredel'skij AA. Sport i illiuziia sporta [Sports and illusion of sports], Moscow; 2011. (in Russian)

17. Rajgorodskij DIa. Prakticheskaia psikhodiagnostika [Practical psycho-diagnostic], Samara: Bahrah-M; 2001. (in Russian)

18. Rutan Dzh, Stoun U. Psikhodinamicheskaia gruppovaia psikhoterapiia [Psycho-dynamic group psychotherapy], Sankt Petersburg; 2002. (in Russian)

19. Skejfi S. Dialektika art-terapii [Dialectic of art-therapy], Sankt Petersburg; 2001. (in Russian)

20. Sopov VF. Psikhicheskie sostoianiia v napriazhennoj professional'noj deiatel'nosti [Psychic states in tensed professional functioning], Moscow: Triksta; 2005. (in Russian)

21. Uajteker P. Dvizhenie, improvizaciia i telesnye oshchushcheniia v art-terapii [Movements, improvising and body feeling in art therapy], Isceliaiushchee iskusstvo, 2002;5(1): 37-39. (in Russian)

22. Chikova OM. Psikhologicheskie osobennosti sportivnoj deiatel'nosti i lichnosti sportsmena [Psychological peculiarities of sport functioning and sportsman's personality], Minsk; 1993. (in Russian)

23. Enciklopediia psikhodiagnostiki. Psikhodiagnostika vzroslykh. [Encyclopedia of psycho-diagnostic. Psychodiagnostic of adults]. Samara; 2009. (in Russian)

24. Aghyppo A, Tkachov S, Orlenko O. Role of physical education on the formation of a healthy lifestyle outside of school hours. Journal of Physical Education and Sport, 2016;16(2):335 - 339.

25. Belcaro G. Pycnogenol ${ }^{\circledR}$ Improves cognitive function, attention, mental performance and specific professional skills in healthy professionals age 35-55. J Neurosurg Sci, 2014;58: 239-248.

26. Förstl H. Boxing-acute complications and late sequelae: from concussion to dementia. Dtsch Arztebl Int, 2010;107(47): 835-839.

27. Gavett BE, Stern RA, McKee AC. Chronic traumatic encephalopathy: a potential late effect of sport-related concussive and subconcussive head trauma. Clinics in sports medicine, 2011;30(1): 179-188.

28. Iermakov S, Podrigalo L, Romanenko V, Tropin Y, Boychenko N, Rovnaya O, Kamaev O. Psychophysiological features of sportsmen in impact and throwing martial arts. Journal of Physical Education and Sport, 2016;16(2):433-441. doi:10.7752/jpes.2016.02067

29. Luzzi R. Pycnogenol ${ }^{\circledR}$ supplementation improves cognitive function, attention and mental performance in students. Panminerva medica, 2011;53(3):75-82.

30. Neselius S. CSF-biomarkers in Olympic boxing: diagnosis and effects of repetitive head trauma. PloS one, 2012;7(4): 533-606.

31. Slobodanka Gašić-Pavišić, Snežana Joksimović, Dragan Janjetović. General Self-Esteem And Locus Of Control Of Young Sportsmen. Zbornik Instituta za pedagoshka istrazhivana, 2006;38:385-400. 


\begin{tabular}{|c|}
\hline Information about the authors: \\
\hline $\begin{array}{l}\text { Gant H.Y.; http://orcid.org/0000-0001-7729-4914; } \\
\text { lena.gant@mail.ru; Kharkov State Academy of Physical } \\
\text { Culture; Klochkovskaya str. 99, Kharkov, 61022, Ukraine. } \\
\text { Orlenko O.M.; http://orcid.org/0000-0003-4436-487X; } \\
\text { helenne-86@mail.ru; Kharkov State Academy of Physical } \\
\text { Culture; Klochkovskaya str. 99, Kharkov, 61022, Ukraine. }\end{array}$ \\
\hline $\begin{array}{l}\text { Cite this article as: Gant H.Y., Orlenko O.M. Psychological } \\
\text { means of recreation sportsmen's psychic }\end{array}$ \\
\hline $\begin{array}{l}\text { The electronic version of this article is the complete one and can be } \\
\text { found online at: http://www.sportpedu.org.ua/html/arhive-e.html }\end{array}$ \\
\hline $\begin{array}{l}\text { This is an Open Access article distributed under the terms of the } \\
\text { Creative Commons Attribution License, which permits unrestricted } \\
\text { use, distribution, and reproduction in any medium, provided the } \\
\text { original } \quad \text { work } \quad \text { is properly } \\
\text { (http://creativecommons.org/licenses/by/4.0/deed.en). }\end{array}$ \\
\hline $\begin{array}{l}\text { Received: } 04.10 .2016 \\
\text { Accepted: } 19.10 .2016 \text {; Published: } 28.10 .2016\end{array}$ \\
\hline
\end{tabular}

